\title{
ANALISIS KESULITAN BELAJAR SISWA PADA MATERI POKOK SEL HEWAN DAN TUMBUHAN DI KELAS XI IPA SMA SWASTA ESA PRAKARSA
}

\author{
Dewi Rulia Br Sitepu \\ Dosen STKIP Budidaya Binjai \\ e-mail: dewiruliasitepu@ gmail.com
}

\begin{abstract}
ABSTRAK
Penelitian ini bertujuan untuk mengetahui kesulitan - kesulitan yang dihadapi siswa dalam mempelajari materi pokok Sel Hewan dan Tumbuhan di Kelas XI IPA SMA Swasta Esa Prakarsa. Subjek dalam penelitian ini adalah siswa kelas XI IPA SMA Swasta Esa Prakarsa.. Objek dalam penelitian ini adalah hasil kesulitan siswa yang dihadapi siswa dalam mempelajari materi pokok Sel Hewan dan Tumbuhan. Jenis penelitian ini adalah penelitian deskriptif. Penelitian deskriptif dilakukan untuk memperoleh unformasi tentang suatu status gejala pada saat penelitian dan dapat digunakan untuk pengambilan keputusan. Instrumen yang digunakan dalam penelitian ini adalah tes yang hasil berbentuk presentase. Hasil penelitian menunjukkan bahwa banyak siswa yang masih kesulitan dalam berbagai jenis. Data menunjukkan bahwa jenis kesulitan yang paling dominan adalah kesulitan operasi yaitu sebesar 81,3\%. Dengan demikian dapat disimpulkan bahwa siswa di kelas XI IPA SMA Swasta Esa Prakarsa masih sangat sulit dalam mempelajari materi pokok Sel Hewan dan Tumbuhan.
\end{abstract}

Kata kunci : Kesulitan belajar, sel hewan dan tumbuhan

\section{PENDAHULUAN}

Pendidikan merupakan salah

satu faktor yang sangat penting dalam meningkatkan sumber daya manusia. Sejalan dengan ilmu pengetahuan dan teknologi, manusia dituntut untuk meningkatkan mutu pendidikannya. Berbicara tentang mutu pendidikan tentu tidak terlepas dari keberhasilan siswa dalam belajar, hal ini dapat dilihat dari prestasi belajar yang diperolehnya. Prestasi belajar yang tinggi menunjukkan bahwa siswa berhasil dalam belajarnya sedangkan prestasi belajar yang rendah menunjukkan bahwa siswa tidak berhasil dalam belajarnya.
Materi biologi yang ada sekarang ini sangat sarat dengan istilah-istilah biologi yang sebagian besar diambil dari bahasa latin sehingga hilangnya konsep-konsep penting yang sebenarnya belum dipahami oleh siswa. Ditambah lagi dengan kurang sesuainya strategi belajar yang digunakan pengajar sehingga siswa tidak mampu menuntaskan belajarnya. Keberhasilan siswa dalam kegiatan belajar mengajar adalah hal yang sangat diharapkan, namun tidak jarang berbagai kendala yang terjadi mengakibatkan siswa kurang mampu mencapai 


\section{Jurnal Serunai Ilmu Pendidikan \\ Vol.5, No.2, Desember 2019 \\ e-ISSN 2621 - 2676}

hasil sebagaimana yang diharapkan. Dimana, berdasarkan informasi yang diperoleh dari survey pendahuluan yang dilakukan memperlihatkan satu kenyataan bahwa hasil belajar Biologi dalam mempelajari sub materi pokok Sel Hewan dan Tumbuhan masih banyak dibawah standar Kriteria Ketuntasan Minimal (KKM) yang telah ditetapkan sekolah yaitu sekitar 65\%. Berkaitan dengan kondisi ini, diperkirakan siswa mengalami kesulitan dalam mempelajari sub materi pokok tersebut.

Adapun kendala-kendala yang dihadapi siswa dalam memahami materi biologi yaitu sub materi pokok sel hewan dan tumbuhan antara lain : (1) siswa kurang aktif untuk mencari gambar-gambar dan penjelasan tambahan tentang sel hewan dan tumbuhan yang tidak ada di buku pegangan siswa, (2) rendahnya kemampuan siswa mengingat materi pelajaran yang telah diajarkan dan (3) kurang tersedianya alat peraga sel hewan dan tumbuhan di sekolah.

Kita mengetahui bersama bahwa mutu pendidikan di Indonesia masih rendah. Hal ini dapat dilihat dari posisi mutu pendidikan negara kita saat ini yang berada pada urutan 102 dari 107 negara. Dan untuk tingkat Asia dari 47 negara, posisi Indonesia ada di angka 41 (Sjamsulbachri, 2007). Pemerintah telah melakukan berbagai cara dan usaha untuk memperbaiki dan meningkatkan mutu pendidikan. Hal ini bertujuan agar Pendidikan
Nasional dapat tercapai. Sistem pendidikan nasional sebagai suatu organisasi dituntut untuk selalu dinamis dan fleksibel sehingga dapat mengikuti perubahan-perubahan dalam perkembangan ilmu pengetahuan dan teknologi.

Dalam Sitepu (2017) menyatakan bahwa untuk meningkatkan mutu pendidikan salah satunya maka guru harus mampu membuat perencanaan pembelajaran, proses pelaksanaan pembelajaran dan penilaian hasil belajar yang baik dan ini akan terwujud bila guru memenuhi kualifikas seperti yang diinginkan Peraturan Pemerintah No 19 tahun 2005 pada Standart Nasional Pendidikan dan Permendiknas no 16 Tahun 2007 tentang Standar Pendidik dan Tenaga Kependidikan yang menyebutkan guru harus berpendidikan minimal Sarjana / Diploma IV dan mengajar mata pelajaran harus sesuai dengan latar belakang pendidikannya atau spesialisnya.

Setiap materi pelajaran tentu memiliki tingkat kesukaran yang bervariasi (Sitepu, 2019). Salah satu indikator kesulitan siswa dalam belajar adalah ketidakmampuan anak untuk menampakkan salah satu dari beberapa kemampuan akademik. Kemampuan ini menyangkut aspek kognitif, afektif dan psikomotor (Depdiknas, 2003). Oleh karena itu diperlukan solusi yang tepat guna mengatasi kesulitan belajar yang berdampak pada rendahnya prestasi belajar. 
Prestasi belajar yang rendah khususnya biologi menunjukkan adanya kesulitan dalam belajar biologi. Anak berkesulitan belajar memperoleh prestasi belajar jauh dibawah prestasi yang dimilikinya (Abdurrahman, 2005).

Untuk memahami beberapa besar tingkat kesulitan dan titik kesulitan siswa dalam belajar, maka dapat dilakukan dengan berbagai cara. Salah satunya adalah menganalisis hasil evaluasi belajar siswa. Gambaran tingkat kesulitan belajar akan dapat terlihat dari hasil evaluasi belajar mereka. Berdasarkan hasil analisis tersebut pendidik dapat menentukan solusi terbaik bagi siswa hingga siswa mampu mencapai hasil belajar sesuai dengan yang diharapkan.

\section{METODE PENELITIAN}

Jenis penelitian ini adalah penelitian deskriptif. Penelitian ini dilakukan untuk menganalisis kesulitan-kesulitan siswa dalam mempelajari materi pokok Sel Hewan dan Tumbuhan . Penelitian biasanya tidak diarahkan untuk menguji hipotesis, melainkan mencari informasi yang dapat digunakan untuk pengambilan keputusan.

Subjek dalam penelitian ini adalah siswa kelas XI IPA SMA Swasta Esa Prakarsa. Objek dalam penelitian ini adalah hasil kesulitan siswa yang dihadapi siswa dalam mempelajari materi pokok Sel Hewan dan Tumbuhan
Instrumen yang digunakan dalam penelitian ini adalah tes. Tes dalam penelitian ini membuat soal uraian sebanyak 5 butir yang berisi tentang materi pokok Sel Hewan dan Tumbuhan

Analisis penilaian siswa dilakukan dengan menghitung presentase siswa yang mengalami kesulitan setiap tahap dari soal yang diberikan, digunakan rumus sebagai berikut:

$$
P=\frac{F}{N} \times 100 \%
$$

Menurut

Sujdono (dalam Nisa' 2011:32)

Keterangan :

$\mathrm{P}=$ presentase siswa yang mengalami kesulitan belajar

$\mathrm{F}$ = frekuensi siswa yang mengalami kesulitan belajar

$\mathrm{N}=$ banyaknya siswa

Adapun presentase tingkat kesulitan siswa dapat dikategorikan sebagai berikut:

$0 \%<\mathrm{P}<20 \%$ tergolong sangat rendah

$20 \%<\mathrm{P}<40 \%$ tergolong rendah

$40 \%<\mathrm{P}<60 \%$ tergolong cukup

$60 \%<\mathrm{P}<80 \%$ tergolong tinggi

$80 \%<\mathrm{P}<100 \%$ tergolong sangat tinggi

\section{HASIL DAN PEMBAHASAN}

Tes yang diberikan pada siswa dapat menggambarkan data tentang kesulitan-kesulitan mempelajari materi pokok Sel Hewan dan Tumbuhan. Selesai tes dilaksanakan maka 
lembaran jawaban seluruh siswa tersebut dikoreksi dalam suatu lembaran tabulasi yang sudah dipersiapkan ditandai pada langkah mana siswa menjawab benar atau melakukan kesalahan sebagaimana dalam rekapitulasi jawaban siswa di tes soal.

Adapun kendala-kendala yang dihadapi siswa dalam memahami materi biologi yaitu sub materi pokok keanekaragaman hayati dan pelestariannya antara lain : (1) siswa kurang aktif untuk mencari gambar-gambar dan penjelasan tambahan tentang keanekaragaman hayati dan pelestariannya yang tidak ada di buku pegangan siswa, (2) rendahnya kemampuan siswa mengingat materi pelajaran yang telah diajarkan dan (3) kurang tersedianya alat peraga keanekaragaman hayati dan pelestariannya di sekolah.

Setelah hasil akhir diperiksa, diperoleh persentasi jenis kesulitan yaitu kesulitan fakta sebesar 44,7 \%, kesulitan Konsep sebesar $16 \%$, kesulitan Operasi sebesar 81,3 \% dan kesulitan Prinsip sebesar 22 \%. Untuk lebih lengkapnya, dapat dilihat pada diagram berikut ini :

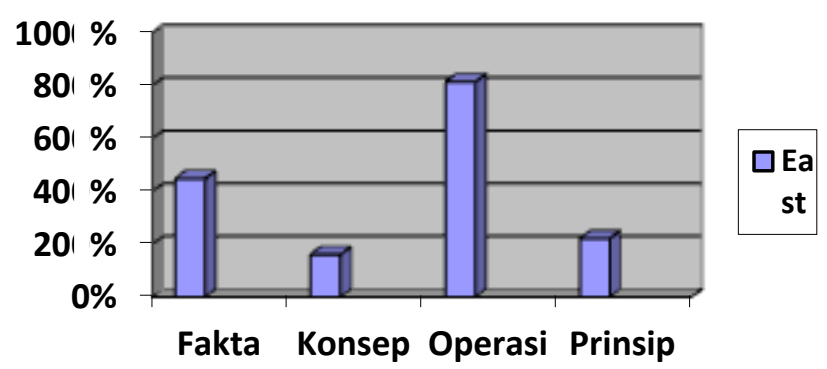

Pembahasan Penelitian

1. Rata-rata kesulitan fakta siswa dalam mempelajari materi pokok Sel Hewan dan Tumbuhan adalah 44,7 \%.

2. Rata-rata kesulitan konsep siswa dalam mempelajari materi pokok Sel Hewan dan Tumbuhan adalah $16 \%$.

3. Rata-rata kesulitan operasi siswa dalam mempelajari materi pokok Sel Hewan dan Tumbuhan adalah $81,3 \%$.

4. Rata-rata kesulitan prinsip siswa dalam mempelajari materi pokok Sel Hewan dan Tumbuhan adalah $22 \%$.

Yang artinya kesulitan siswa di kelas XI SMA Swasta Esa Prakarsa dalam mempelajari materi pokok Sel Hewan dan Tumbuhan dominan terletak pada jenis kesulitan operasi yaitu sebesar $81,3 \%$.

Seiring perkembangan zaman, dunia pendidikan juga memerlukan berbagai inovasi. Hal itu penting dilakukan untuk kemajuan kualitas pendidikan sesuai dengan yang dikemukakan oleh Soejadi dalam Sitepu (2019) bahwa "Kegiatan pembelajaran IPA di jenjang persekolahan merupakan suatu kegiatan yang harus dikaji terus menerus dan jika perlu diperbaharui agar dapat sesuai dengan kemampuan murid serta tuntutan lingkungan. 


\section{KESIMPULAN}

Adapun kesimpulan dari penelitian ini adalah analisis kesulitan siswa dalam mempelajari materi pokok Sel Hewan dan Tumbuhan

Siswa kesulitan fakta dalam mempelajari materi pokok Sel Hewan dan Tumbuhan pada kriteria cukup sulit.

a. Siswa kesulitan konsep dalam mempelajari materi pokok Sel Hewan dan Tumbuhan pada kriteria rendah.

b. Siswa kesulitan operasi dalam mempelajari materi pokok Sel Hewan dan Tumbuhan pada kriteria sangat tinggi atau sangat sulit.

c. Siswa kesulitan prinsip dalam mempelajari materi pokok Sel Hewan dan Tumbuhan pada kriteria rendah.

Yang artinya kesulitan siswa di kelas XI IPA SMA Swasta Esa Prakarsa dalam menyelesaikan soal fungsi komposisi dominan terletak pada jenis kesulitan operasi yaitu sebesar $81,3 \%$.

\section{DAFTAR RUJUKAN}

Abdurrahman, M. 2005, Pendidikan Bagi Anak Berkesulitan Belajar, Penerbit Rineka Cipta, Jakarta.

Ahmadi, A., 2005, Psikologi Umum, PT Rineka Cipta, Jakarta
Arikunto, S., 2003, Dasar-Dasar Evaluasi Pendidikan, Penerbit Bina Aksara Bandung.

Depdiknas, 2003, Kurikulum 2004 SMA. Pedoman Khusus Pengembangan Silabus dan penilaian. Mata pelajaran Biologi. Jakarta. Depdiknas.

Hamalik, 2004, Metode Belajar Dan Kesulitan Kesulitan Belajar, Tarsito, Bandung.

Purwanto, M.N., 2004, Psikologi Pendidikan, Penerbit Remaja Rosda Karya, Bandung.

Sitepu, DRB. 2017. Analisis Kesulitan Guru IPA Terpadu dalam Mengajar Materi Biologi di SMP Negeri Kota Binjai T.P. 2010/2011. Prosiding Seminar Nasional Dies Natalis ke-27, STKIP Budidaya Binjai.

Sitepu, DRB. 2019. Penerapan Model Quantum Teaching Pada Pembelajaran Biologi Materi Pokok Sistem Ekskresi Manusia Di Kelas XI IPA SMA Swasta Esa Prakarsa. Prosiding Seminar Nasional Multidisiplin Ilmu Universitas Asahan.

Sitepu, DRB. 2019. Perbandingan Hasil Belajar Siswa Dengan Menggunakan Media Audiovisual Dan Tanpa Media Audiovisual Pada Materi Struktur Dan Fungsi Sel Sebagai Unit Terkecil Kehidupan Di Kelas XI SMA Swasta Esa Prakarsa T.A 2018/2019. J. Serunai Ilmu Pendidikan Vol.5. No.1, STKIP Budidaya, Binjai.

Sjamsulbachri, H.A., 2007, Profesionalisme Guru Sebuah Harapan: http/www.geocities.com/guruvalah/artikelpendidikan/html

Slemeto, 2003, Belajar Dan Faktor-Faktor Yang Mempengaruhinya, PT. Rhineka Cipta, Jakarta. 
Sudjana, 1993, Metode Statistika, Jilid 2, Tarsito, Bandung.

Sukmadinata, N.S., 2004, Landasan Psikologi Proses Pendidikan, Penerbit Remaja Rosda Karya, Bandung..

Syah, M., (2003), Psikologi Belajar, Penerbit Raja Grafindo Persada, Jakarta.

Tim Dosen Belajar dan Pembelajaran Unimed, 2004, Belajar dan Pembelajaran, FMIPA UNIMED, Medan.

Tim Dosen Metode Penelitian Unimed, 2006, Metode Penelitian, FMIPA UNIMED Medan. 